\title{
Using genomic resources for linkage analysis in Peromyscus with an application for characterizing Dominant Spot
}

\author{
Zhenhua Shang, David J. Horovitz, Ronald H. McKenzie, Jessica L. Keisler, Michael R. Felder and
} Shannon W. Davis ${ }^{*}$ (1)

\begin{abstract}
Background: Peromyscus are the most common mammalian species in North America and are widely used in both laboratory and field studies. The deer mouse, P. maniculatus and the old-field mouse, P. polionotus, are closely related and can generate viable and fertile hybrid offspring. The ability to generate hybrid offspring, coupled with developing genomic resources, enables researchers to conduct linkage analysis studies to identify genomic loci associated with specific traits.

Results: We used available genomic data to identify DNA polymorphisms between P. maniculatus and P. polionotus and used the polymorphic data to identify the range of genetic complexity that underlies physiological and behavioral differences between the species, including cholesterol metabolism and genes associated with autism. In addition, we used the polymorphic data to conduct a candidate gene linkage analysis for the Dominant spot trait and determined that Dominant spot is linked to a region of chromosome 20 that contains a strong candidate gene, Sox10. During the linkage analysis, we found that the spot size varied quantitively in affected Peromyscus based on genetic background.

Conclusions: The expanding genomic resources for Peromyscus facilitate their use in linkage analysis studies, enabling the identification of loci associated with specific traits. More specifically, we have linked a coat color spotting phenotype, Dominant spot, with Sox10, a member the neural crest gene regulatory network, and that there are likely two genetic modifiers that interact with Dominant spot. These results establish Peromyscus as a model system for identifying new alleles of the neural crest gene regulatory network.
\end{abstract}

Keywords: Peromyscus, Neural crest, Sox10, Genomic, DNA polymorphism

\section{Background}

Peromyscus are the most common and widely distributed mammalian species in North America and includes the deer mouse ( $P$. maniculatus), the old-field mouse ( $P$. polionotus), and the white-footed mouse (P. leucopos) [1]. Peromyscus have similar characteristics to old world mice, including the house mouse, Mus musculus, which

\footnotetext{
* Correspondence: swdavis@mailbox.sc.edu

Department of Biological Sciences, University of South Carolina, Columbia, SC 29208, USA
}

(C) The Author(s). 2020 Open Access This article is licensed under a Creative Commons Attribution 4.0 International License, which permits use, sharing, adaptation, distribution and reproduction in any medium or format, as long as you give appropriate credit to the original author(s) and the source, provide a link to the Creative Commons licence, and indicate if changes were made. The images or other third party material in this article are included in the article's Creative Commons licence, unless indicated otherwise in a credit line to the material. If material is not included in the article's Creative Commons licence and your intended use is not permitted by statutory regulation or exceeds the permitted use, you will need to obtain permission directly from the copyright holder. To view a copy of this licence, visit http://creativecommons.org/licenses/by/4.0/ The Creative Commons Public Domain Dedication waiver (http://creativecommons.org/publicdomain/zero/1.0/) applies to the data made available in this article, unless otherwise stated in a credit line to the data.

is the most widely used model system for biomedical research. However, Peromyscus and Mus are more distantly related than their appearance suggests, sharing a last common ancestor 25 million years ago [2]. Peromyscus are more closely related to hamsters than to Mus.

Mus is an exceptional model system for biomedical research, having a wide range of genetic resources, including a fully sequenced and annotated genome, various inbred strains, and the ability to make specific genetic modifications. However, in developing Mus laboratory 
strains, human selection resulted in a genome with contributions from three different Mus species, and the process of inbreeding resulted in a lack of genetic diversity [3]. As a result, genome wide association studies (GWAS) using Mus typically produce linkage to genomic intervals that are too large to facilitate candidate gene identification [4]. Furthermore, the lack of genetic diversity has reduced the pool of traits that could be identified and eventually characterized in laboratory mice. Recognizing the limitations of inbred Mus lines for GWAS and quantitative trait locus (QTL) mapping studies, the Collaborative Cross was initiated to generate genomic variation by combining eight inbred lines and three wild subspecies of Mus [5, 6]. By intercrossing the Collaborative Cross strains, a Diversity Outbred stock was generated to reduce the linkage disequilibrium blocks characteristic of the founder inbred lines [6, 7]. The Diversity Outbred stock has been used to map numerous quantitative traits observed in the founding inbred lines, including serum cholesterol levels and heart size $[6,8,9]$.

Another option is to use the variation observed in existing outbred stocks to generate smaller linked intervals that facilitate gene discovery. For instance, a GWAS study conducted on outbred Mus stocks for variability in high density lipoprotein and hypercholesterolemia produced a linked interval of less than $100 \mathrm{~kb}$, which lead to the identification of allelic differences in Apoa 2 associated with hypercholesterolemia [10]. The key to generating small linked intervals is the frequency of genetic variation. In inbred strains, the lack of genetic variation generates long syntenic regions that result in large blocks of linkage disequilibrium. Peromyscus bred in captivity are susceptible to inbreeding depression; therefore, the Peromyscus Genetic Stock Center (PGSC) at the University of South Carolina (UofSC) maintains outbred stocks of $P$. maniculatus (BW), P. polionotus (PO), and $P$. leucopus (LL). These stocks are maintained by breeding individuals that do not have a common grandparent [11]. Because these outbred stocks have not undergone intentional selection, they maintain both genetic and phenotypic diversity, similar to natural populations $[1,12]$. These genetically diverse laboratory stocks provide another animal model with physiological and behavior variation that differs from the Diversity Outbred stocks and other outbred Mus stocks, providing an opportunity to study how genetic variation may predispose individuals to disease $[13,14]$. Additional genetic variation can be generated in Peromyscus because P. maniculatus and $P$. polionotus can produce viable and fertile hybrid offspring [1].

$P$. maniculatus and $P$. polionotus are species with distinct behavioral and metabolic differences [1]. The ability to generate hybrids between two Peromsycus outbred stocks enables researchers to use QTL analysis to identify genetic loci that underlie the quantitative traits, behavior, or metabolic differences between the two species. For instance, $P$. polionotus build better nests than $P$. maniculatus [15]. A QTL associated with nest building is located on chromosome 4 , and the vasopressin gene is located within the QTL. There are no non-synonymous changes in the coding region of vasopressin between the two species; however, P. maniculatus express 2.8 -fold more vasopressin mRNA in the hypothalamus than $P$. polionotus. This species-specific expression difference results in the species-specific nest building behaviors, as increasing vasopressin in $P$. polionotus inhibits nest building behavior [15]. Other QTL analyses utilizing $P$. maniculatus and $P$. polionotus have identified genetic loci associated with coat color differences and burrowing behavior [16, 17].

There are many behavioral differences between $P$. maniculatus and $P$. polionotus that are associated with human health. For instance, The BW stock of $P$. maniculatus has a high incidence of repetitive behavior, while the PO stock of $P$. polionotus has no repetitive behavior $[18,19]$. In humans, repetitive behavior is observed in people with autism and obsessive-compulsive disorder [20]. A QTL analysis for repetitive behavior using $P$. maniculatus and $P$. polionotus hybrids could identify the genetic loci associated with this behavior and provide an animal model for understanding complex behaviors associated with human disease.

The genomic tools that facilitate QTL analysis in Peromyscus are actively being developed. The first genomic assembly containing almost 31,000 scaffolds of $P$. maniculatus was released in 2013 (GenBank assembly GCA 000500345.1). Raw whole genome sequencing reads for $P$. polionotus were deposited in the Sequencing Read Archive (SRA) in July 2015 (SRX179420, SRX179421, and SRX179422). An improved, chromosome level assembly for $P$. maniculatus followed in November of 2018 (GenBank assembly GCA_003704035.1), along with chromosome level assemblies of $P$. polionotus (GenBank assembly GCA_003704135.2) and P. leucopus (GenBank assembly GCA_004664715.1), in April of 2019 [21]. These resources facilitate the design of linkage mapping studies by providing species specific allelic information across the genome. Restriction site-associated DNA sequencing, RADseq, and its variant double digest RADseq, ddRADseq, facilitate linkage mapping studies by providing high throughput genome wide allelic information, and have been instrumental in several Peromyscus QTL studies [15, $16,22,23]$. While a reference genome is not necessary for RADseq experiments, it facilitates these experiments by providing a scaffold on which to map allelic information. 
The continued development of Peromyscus genomic resources is required to facilitate linkage analysis studies in Peromyscus. We performed a comparative analysis of the $P$. maniculatus and $P$. polionotus genomes, using available genomic datasets, to identify polymorphisms between the two species that can be used for linkage analysis. We used the polymorphic data to design a candidate gene linkage mapping study to identify a genetic locus associated with the Dominant spot trait in P. maniculatus. This information was also used to identify genetic differences associated with known physiological and behavioral differences between the two species.

\section{Results}

\section{Analysis of genomic variations between $P$. maniculatus and $P$. polionotus}

The ability to generate fertile and viable hybrid offspring from $P$. maniculatus and $P$. polionotus provides an opportunity to identify the genetic loci associated with phenotypic traits that differ between the two species. Capitalizing on this rich genetic resource requires identifying the allelic differences between the two species. We sought to identify allelic differences between $P$. maniculatus and $P$. polionotus, using publicly available genomic resources. The first assembly of the $P$. maniculatus genome was used as the reference genome, and the $P$. polionotus sequencing reads deposited in the SRA database were mapped against the $P$. maniculatus reference genome. For polymorphism determination we required 10 independent $P$. polionotus sequencing reads to be mapped to a specific $P$. maniculatus genomic location (data file available at https://osf.io/4eypx/). With these criteria we determined that $81.9 \%$ of the $P$. maniculatus genome was covered by $10 \mathrm{P}$. polionotus sequencing

Table 1 Characterization of variants

\begin{tabular}{ll}
\hline Variant Type & Count \\
\hline SNP & $34,084,607$ \\
Insertion & $2,038,754$ \\
Deletion & $2,042,973$ \\
Transcript & $45,591,302$ \\
EXON & 769,092 \\
5' UTR & 96,746 \\
3' UTR & 490,685 \\
INTRON & $44,630,345$ \\
Splice Acceptor & 1215 \\
Splice Donor & 1327 \\
Splicing Region & 87,301 \\
Intergenic & $23,148,376$ \\
5 kb Upstream & $7,302,504$ \\
5 kb Downstream & $7,337,171$ \\
\hline
\end{tabular}

reads, resulting in 38,166,334 polymorphisms between $P$. maniculatus and $P$. polionotus. Among these variations are 34,084,607 single nucleotide polymorphisms (SNPs) and 4,081,727 insertions or deletions (INDELs) between $\mathrm{BW}$ and PO (Table 1). Lowering the read mapping requirement to five sequencing reads increased the number of identified polymorphisms to 40,815,360. However, we chose to keep the more stringent criteria for subsequent analysis, recognizing that we are likely underestimating the number of polymorphisms between the species. Using the more stringent $38,166,334$ polymorphisms results in a variant rate of one variation every 68 base pairs. We used SnpEff to annotate the potential functional effects of the polymorphisms (data file available at https://osf.io/4eypx/), recognizing that individual variant locations can have multiple annotations, which increases the number of annotations above the total number of variants. More than 23 million variants occur in intergenic regions, with more than 7 million occurring within $5 \mathrm{~kb}$ upstream or downstream of an annotated gene, potential impacting transcriptional regulatory sites (Table 1). More than 45 million variants occur in an annotated transcript region, including $>769,000$ in annotated exons and $>44$ million in annotated introns (Table 1). Within exons, the majority occur in 3 ' untranslated regions (UTR).

We characterized the SNPs that occur between $P$. maniculatus and $P$. polionotus for changes in predicted protein coding sequences and found that there are 11, 588 genes that contain a coding sequence SNP. Of these variants, $70.2 \%$ are silent, $29.6 \%$ are missense, and $0.2 \%$ are nonsense variants. We identified a set of 10,405 genes that contain a nonsynonymous change, which might result in a functional difference in the protein between the two species. Using the annotated Mus genome as a reference, we conducted a gene ontology (GO) term analysis on the list of 10,405 genes with missense or nonsense variants to determine if any biological processes or molecular functions are over or underrepresented within this list of genes. There are 2060 biological processes that are over-represented, and 63 that are under-represented (Table 2 and Additional Files 1 and 2 ). The processes with the most statistically significant enrichment are typically broad in GO terminology, including cellular process, cellular metabolic process, and metabolic process. P. maniculatus and $P$. polionotus are known to have distinct physiological differences, including an almost four-fold increase in blood cholesterol levels in P. polionotus compared to P. maniculatus and a two-fold increase in blood triglyceride levels in $P$. polionotus over P. maniculatus [24]. We searched the list of overrepresented GO terms for terms with a possible relationship with cholesterol and triglycerides and found that the GO terms cholesterol metabolic process, 
Table 2 Top 20 over and underrepresented GO terms in the list of Peromyscus genes containing a nonsynonymous SNP between $P$. maniculatus and $P$. polionotus

\begin{tabular}{|c|c|c|c|c|c|}
\hline Overrepresented GO terms & GO term ID & $p$-value & $\begin{array}{l}\text { Number of Mus } \\
\text { genes with } \\
\text { GO term }\end{array}$ & $\begin{array}{l}\text { Expected } \\
\text { number of } \\
\text { genes }\end{array}$ & $\begin{array}{l}\text { Number of Peromyscus } \\
\text { Genes with } \\
\text { non-synonymous SNP }\end{array}$ \\
\hline cellular process & GO:0009987 & 2.03E-298 & 15,748 & 6516 & 7781 \\
\hline cellular metabolic process & GO:0044237 & $8.06 \mathrm{E}-257$ & 9331 & 3861 & 5119 \\
\hline metabolic process & GO:0008152 & $2.96 \mathrm{E}-243$ & 10,435 & 4318 & 5557 \\
\hline primary metabolic process & GO:0044238 & $5.83 \mathrm{E}-235$ & 9405 & 3891 & 5096 \\
\hline organic substance metabolic process & GO:0071704 & $8.98 \mathrm{E}-225$ & 9966 & 4124 & 5310 \\
\hline nitrogen compound metabolic process & GO:0006807 & $2.89 \mathrm{E}-214$ & 8892 & 3679 & 4819 \\
\hline cellular component organization or biogenesis & GO:0071840 & $5.56 \mathrm{E}-214$ & 6225 & 2576 & 3618 \\
\hline cellular component organization & GO:0016043 & $9.53 \mathrm{E}-201$ & 6053 & 2505 & 3505 \\
\hline localization & GO:0051179 & $3.18 \mathrm{E}-193$ & 5918 & 2449 & 3423 \\
\hline cellular macromolecule metabolic process & GO:0044260 & $2.50 \mathrm{E}-174$ & 7080 & 2929 & 3905 \\
\hline macromolecule metabolic process & GO:0043170 & $3.99 \mathrm{E}-170$ & 8461 & 3501 & 4506 \\
\hline organonitrogen compound metabolic process & GO:1901564 & $9.62 \mathrm{E}-137$ & 6215 & 2572 & 3402 \\
\hline developmental process & GO:0032502 & 4.23E-136 & 6193 & 2562 & 3390 \\
\hline anatomical structure development & GO:0048856 & $1.40 \mathrm{E}-130$ & 5810 & 2404 & 3198 \\
\hline establishment of localization & GO:0051234 & $1.11 \mathrm{E}-127$ & 4518 & 1869 & 2588 \\
\hline biological regulation & GO:0065007 & $1.61 \mathrm{E}-120$ & 12,092 & 5003 & 5874 \\
\hline multicellular organism development & GO:0007275 & $1.36 \mathrm{E}-119$ & 5304 & 2195 & 2931 \\
\hline transport & GO:0006810 & 4.07E-118 & 4378 & 1811 & 2494 \\
\hline organelle organization & GO:0006996 & $2.00 \mathrm{E}-117$ & 3549 & 1468 & 2095 \\
\hline macromolecule modification & GO:0043412 & $7.62 \mathrm{E}-114$ & 3623 & 1499 & 2121 \\
\hline Underrepresented GO terms & GO term ID & $p$-value & $\begin{array}{l}\text { Number of Mus } \\
\text { genes with GO term }\end{array}$ & $\begin{array}{l}\text { Expected } \\
\text { number of } \\
\text { genes }\end{array}$ & $\begin{array}{l}\text { Number of BW } \\
\text { Genes with } \\
\text { non-synonymous SNP }\end{array}$ \\
\hline sensory perception of smell & GO:0007608 & 3.37E-238 & 1138 & 471 & 17 \\
\hline sensory perception of chemical stimulus & GO:0007606 & $2.58 \mathrm{E}-228$ & 1236 & 511 & 39 \\
\hline sensory perception & GO:0007600 & 1.17E-116 & 1784 & 738 & 303 \\
\hline G protein-coupled receptor signaling pathway & GO:0007186 & $2.04 \mathrm{E}-83$ & 1921 & 795 & 410 \\
\hline nervous system process & GO:0050877 & $8.09 \mathrm{E}-55$ & 2286 & 946 & 606 \\
\hline system process & GO:0003008 & $2.91 \mathrm{E}-25$ & 2923 & 1209 & 955 \\
\hline phagocytosis, recognition & GO:0006910 & $3.11 \mathrm{E}-23$ & 151 & 62 & 9 \\
\hline response to pheromone & GO:0019236 & $1.07 \mathrm{E}-21$ & 105 & 43 & 2 \\
\hline complement activation, classical pathway & GO:0006958 & $1.28 \mathrm{E}-19$ & 165 & 68 & 16 \\
\hline $\begin{array}{l}\text { humoral immune response mediated by } \\
\text { circulating immunoglobulin }\end{array}$ & GO:0002455 & $3.89 E-17$ & 180 & 74 & 23 \\
\hline complement activation & GO:0006956 & $1.02 \mathrm{E}-15$ & 187 & 77 & 27 \\
\hline humoral immune response & GO:0006959 & $6.06 \mathrm{E}-15$ & 355 & 147 & 78 \\
\hline phagocytosis, engulfment & GO:0006911 & 4.56E-12 & 189 & 78 & 34 \\
\hline protein activation cascade & GO:0072376 & $1.11 \mathrm{E}-11$ & 200 & 83 & 38 \\
\hline B cell receptor signaling pathway & GO:0050853 & $2.16 \mathrm{E}-11$ & 181 & 75 & 33 \\
\hline xenobiotic metabolic process & GO:0006805 & $2.19 E-11$ & 112 & 46 & 14 \\
\hline plasma membrane invagination & GO:0099024 & $6.36 \mathrm{E}-11$ & 198 & 82 & 39 \\
\hline membrane invagination & GO:0010324 & $1.60 \mathrm{E}-10$ & 205 & 85 & 42 \\
\hline response to leukemia inhibitory factor & GO:1990823 & $1.06 \mathrm{E}-09$ & 311 & 129 & 78 \\
\hline cellular response to leukemia inhibitory factor & GO:1990830 & $1.06 \mathrm{E}-09$ & 311 & 129 & 78 \\
\hline
\end{tabular}


cholesterol homeostasis, cholesterol transport, triglyceride metabolic process, triglyceride biosynthetic process, and triglyceride catabolic process are enriched in this list of genes with potential functional protein changes $(p=$ $3.90 \times 10^{-6}, 3.05 \times 10^{-5}, 3.86 \times 10^{-4}, 9.86 \times 10^{-6}$, and $1.81 \times 10^{-5}$, respectively) (Additional File 1 ). Each of these GO terms contains from 20 to 77 different genes with nonsynonymous changes, suggesting that there is substantial genetic complexity that may underlie the metabolic differences between the two species. In contrast, there are $63 \mathrm{GO}$ terms that are under-represented in the list, including sensory perception of smell, sensory perception of chemical stimulus, sensory perception, G protein-coupled receptor signaling pathway, and nervous system process, suggesting that these biological processes are more conserved between the two species.

The P. maniculatus laboratory stock, BW, is known to have a significant incidence of repetitive, or stereotactic, behavior, including repetitive jumping $[18,25,26]$. The $P$. polionotus laboratory stock, $\mathrm{PO}$, does not display stereotactic behaviors. In humans, repetitive movements are associated with autism, obsessive-compulsive disorder, and other neurologic disorders, including tics and schizophrenia [20, 27]. BW animals have been used to study how neuroactive drugs and environmental enrichment can reduce repetitive behavior $[28,29]$. BW animals are also less social than PO animals, another hallmark of autism in humans $[18,30]$. Our expectation is that there are genetic loci that underlie the stereotactic and social behaviors and we sought to determine if there is genetic variation between BW and PO that may be associated with these behavioral differences. We examined the list of overrepresented GO terms for processes that may be related with autism associated behaviors and found that locomotory behavior and social behavior are both enriched GO terms $\left(p=1.94 \times 10^{-5}\right.$ and $6.79 \times 10^{-4}$, respectively) (Additional File 1). In addition, we selected a list of candidate genes that all have a high confidence of being associated with autism in humans from the Simons Foundation Autism Research Initiative (SFARI) database (Table 3). We then identified sequence variations that occur between $P$. maniculatus and P. polionotus in this list of autism candidate genes. Each gene analyzed has multiple sequence variations between the two species that could result in a functional change to the protein, including missense changes, nonsense changes, in-frame deletions, and nucleotide variations in splicing regions. In addition, there are numerous differences in untranslated regions, introns, and upstream and downstream sequences that could result in differences in transcript or protein levels, if they occur in regulatory regions.

We wanted to further explore how polymorphisms between BW and PO might result in functional changes by examining polymorphisms in one autism candidate gene, recognizing that there are no identified connections between there autism candidate genes and the behavioral differences between BW and PO. ASH1L is a chromatin modifying protein that is associated with transcriptional activation [31]. De novo mutations in ASH1L have been identified in multiple people with autism, while rarely occurring in controls [32-34]. We aligned select mammalian ASH1L protein sequences to identify highly conserved amino acids and determine if Peromyscus amino acid substitutions occur in these conserved residues (Fig. 1). None of the nonsynonymous changes between $P$. maniculatus and $P$. polionotus ASH1L are in the ASH1L conserved protein domains, SET, BROMO, $\mathrm{PHD}$, and $\mathrm{BAH}$, and generally occur in regions with less conservation between mammalian ASH1L proteins. However, at positions 61, 484, 770, 1632, and 2814 there are amino acid substitutions in one Peromyscus species where the amino acid is conserved in the other mammals. The S484A, S770P, and T1632P substitutions are intriguing as they remove potential phosphorylation sites in one of the Peromyscus species. The potential functional impact of these amino acid substitutions on ASH1L function will require further characterization.

We also examined possible transcriptional regulatory changes between $P$. maniculatus and $P$. polionotus for ASH1L by generating a VISTA plot to identify conserved non-coding sequences (CNS) in the ASH1L locus [35]. A conserved non-coding sequence occurs in intron 3 of ASH1L in 100 vertebrate species (UCSC Genome Brower: Human GRCh38/hg38 chromosome 1: 155,459,751-155,478,012) and is also found in BW and PO (Fig. 2) [36]. Within this CNS there are three SNPs between P. maniculatus and P. polionotus. Two of the three Peromyscus SNPs are in positions that are not conserved between a group of seven mammalian species. However, one SNP occurs in a region of 16 nucleotides that are completely conserved within the selection of mammalian species (Fig. 2c). We used PROMO to identify potential transcription factor binding sites within this region and found that in six mammalian species, including $P$. maniculatus, the conserved sequences contain a potential NKX2-1 binding site [37, 38]. However, in P. polionotus the SNP removes the NKX2-1 binding site and generates a potential EBF1 binding site.

\section{Restriction enzyme recognition sites in $P$. maniculatus}

A QTL analysis or GWAS using Peromyscus is likely to utilize RADseq. RADseq is a flexible approach to genomic analysis, as the choice of restriction enzyme used to digest the genomic DNA can be varied to customize the number of sequenced sites, known as RAD markers, across the genome [39]. The number of RAD markers 
Table 3 Polymorphism characterization in Peromyscus genes associated with autism in humans

\begin{tabular}{|c|c|c|c|c|c|c|c|c|c|c|}
\hline Gene & SFARI Score & Upstream & $5^{\prime}$ UTR & Silent & Missense & In-frame deletion & Splice region & Intronic & 3' UTR & Downstream \\
\hline Arid1b & 15 & 205 & & 30 & 6 & & 4 & 5881 & 13 & \\
\hline Adnp & 15 & 75 & & 4 & 3 & & & 175 & 24 & \\
\hline Ashil & $1 S$ & 205 & & 16 & 12 & & 3 & 1089 & 9 & 53 \\
\hline Chd8 & 15 & 155 & 2 & 26 & & & 11 & 663 & 11 & 42 \\
\hline Dyrkla & 15 & 84 & & 4 & & & 1 & 888 & 19 & 82 \\
\hline$K m+2 a$ & $1 \mathrm{~S}$ & 100 & 2 & 39 & 15 & 1 & 5 & 896 & 19 & \\
\hline Tbr1 & 1 & 89 & & 2 & & & 1 & 83 & 1 & \\
\hline
\end{tabular}

generated is twice the number of restriction enzyme recognition sites. An enzyme that cuts more frequently will generate more RAD markers and, therefore, provide more allelic information than an enzyme that cuts less frequently. We used the $P$. maniculatus reference genome to determine the number of cuts sites and the average fragment size for the enzymes listed in Table 4. This data provides a range of restriction enzymes with recognition sites from approximately $1000 \mathrm{bp}$ apart (DraI) to approximately 1 million bp apart (AscI), enabling an informed choice for restriction enzyme selection in $P$. maniculatus RADseq projects. RADseq generates about $400 \mathrm{bp}$ of sequence information flanking a restriction enzyme recognition site. Because a sequence variant between $P$. maniculatus and $P$. polionotus occurs approximately every 68 base pairs, it is likely that RADseq analysis on $F_{1}$ hybrids will generate informative allelic information at most RAD markers.

\section{Linkage analysis of dominant spot}

Dominant spot is a spontaneous mutation that arose within a wild population of $P$. maniculatus near Morrison, Illinois $[1,40]$. The Dominant spot trait $(S)$ is maintained as heterozygotes on the BW laboratory stock of $P$. maniculatus at the PGSC. PGSC breeding records suggest that $S / S$ homozygotes are likely embryonic lethal. We crossed BW $S /+$ adults and generated timed pregnancies and observed resorbing embryos at embryonic day of development 14.5 (e14.5), and approximately one quarter of e13.5 embryos have a variable phenotype that includes morphological defects consistent with embryonic lethality (Fig. 3).

We sought to perform linkage analysis to identify genetic loci associated with Dominant spot by crossing BW $S /+$ (Fig. 4a) with the PO laboratory stock of $P$. polionotus $(+/+) . \mathrm{F}_{1}$ hybrids of $P$. maniculatus and $P$. polionotus exhibit developmental dysgenesis [1, 41]. When female $P$. maniculatus are crossed with male $P$. polionotus, the hybrid offspring are smaller than either parent, but are viable and fertile. In contrast, female $P$. polionotus crossed with male $P$. maniculatus result in overgrown fetuses with developmental defects and are not viable. Therefore, a male $+/+$ PO was crossed with $S /+$ BW to generate six $F_{1}$ hybrids with forehead spots (Fig. 4b). These six $S /+$ offspring were then backcrossed to PO $+/+$ to generate an $\mathrm{N}_{2}$ generation containing 125 animals, of which 46 have spots $(S /+)$ and 79 did not $(+/+)$ (Fig. 4c).

Disrupted pigmentation patterns in laboratory mice, Mus musculus, are readily identifiable, and characterization of the causative mutations for these spotting defects has identified key members of a neural crest gene regulatory network necessary for normal neural crest development [42]. We pursued a candidate gene approach as a first step towards linking Dominant spot with a specific genomic region. Edn3, Ednrb, Kit, Kitl, Mitf, Pax3, Ret, Snail, and Sox10 are all known to cause spotting phenotypes in $M$. musculus; therefore, we sought to identify allelic differences in $P$. maniculatus and $P$. polionotus for each gene to determine if any of these candidate genes are linked with Dominant spot. For our list of candidate genes, we identified a sequence variant that removes a restriction enzyme recognition site in one Peromyscus species. We will call these sites restriction fragment length polymorphisms (RFLPs) because of their similarity to the technique used for genomic variation analysis (Table 5). We then designed polymerase chain reaction (PCR) primers flanking the site to generate an RFLP site specific amplicon. BW and PO genomic DNA, along with genomic DNA from $S /+$ $\mathrm{N}_{2}$ animals was PCR amplified and then digested with the appropriate restriction enzyme (Fig. 5 and Additional File 3). The $S$ mutation arose in $P$. maniculatus and has been maintained on the BW stock; therefore, the $S \mathrm{mu}$ tation occurs in a BW allele. If a candidate gene is linked with the Dominant spot trait, then all $S /+\mathrm{N}_{2}$ animals will have both a BW allele and a PO allele for that candidate gene. If an $S /+\mathrm{N}_{2}$ animal has only PO alleles for a candidate gene, then that candidate gene is not linked with the Dominant spot trait. From our list of candidate genes, eight of the candidate genes are not linked with Dominant spot as there are multiple $S /+\mathrm{N}_{2}$ individuals 


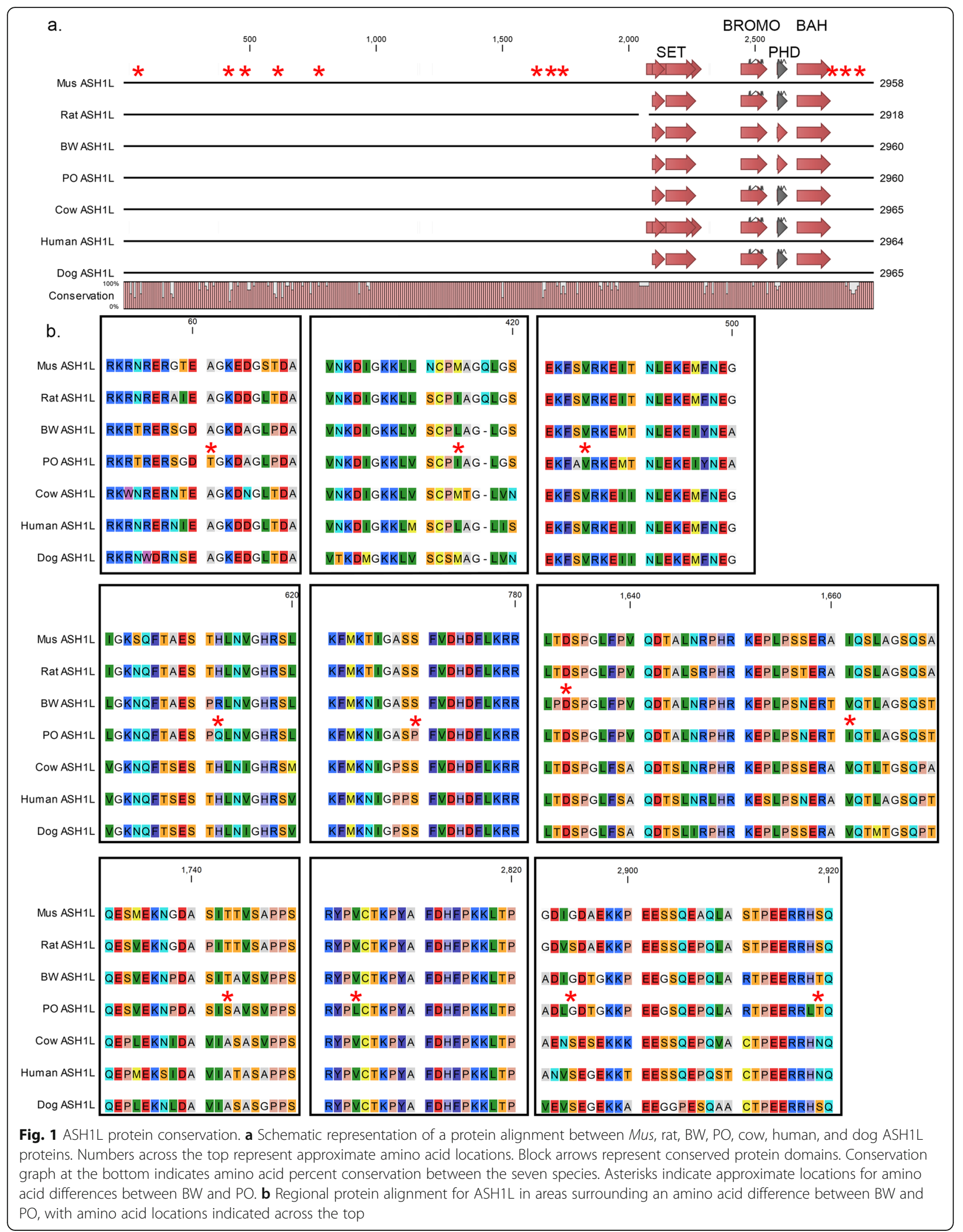


a.

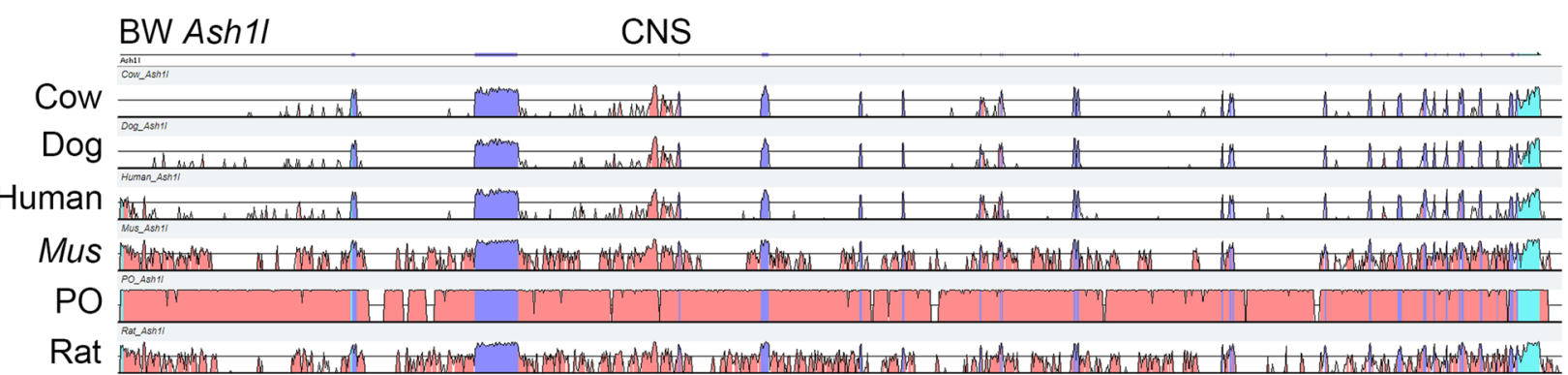

b. CNS region

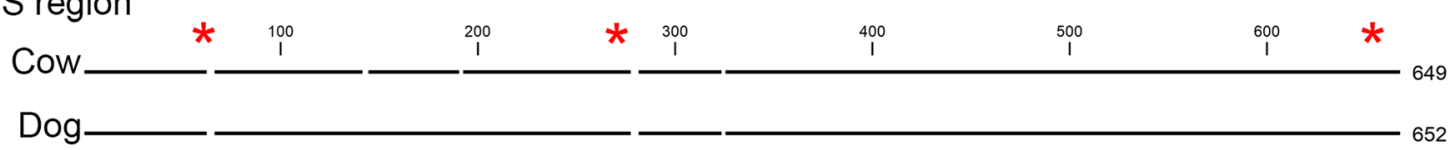

Human 653

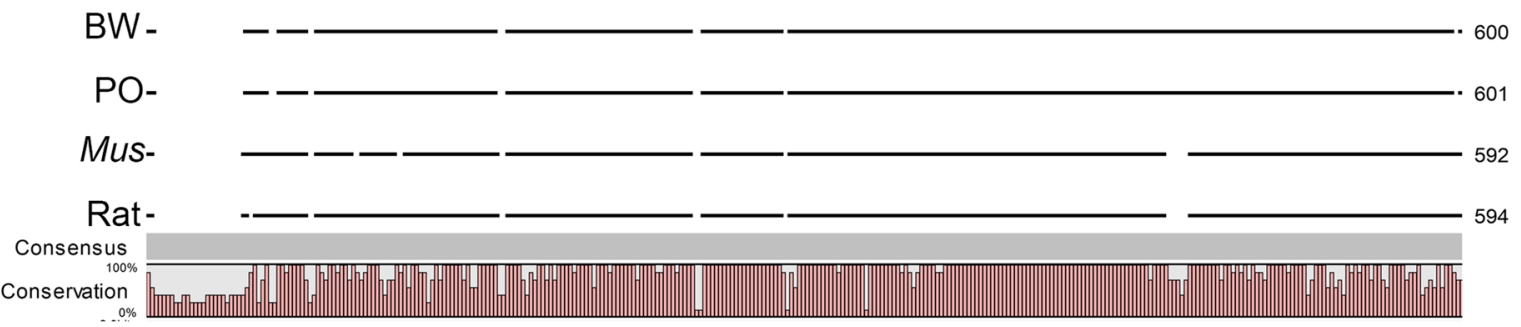

C.

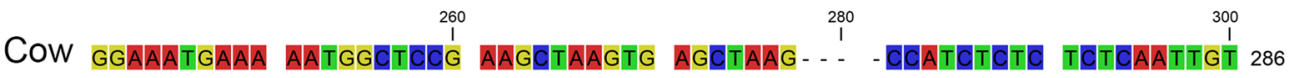

Dog GGAAATGAAA AGTGGCTCAG AAGCTAAGTG AGCTAAG - - - - CCAATGTCTIC TCTCAATTGT 289

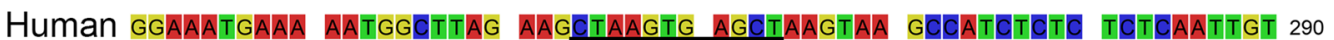
Nkx2-1

BW GAAAATGATA AATGGCTCAAG AAG GTAAGTG AGCTAAG - - - - CCCATCTCTTC TCTCAATTGT 240

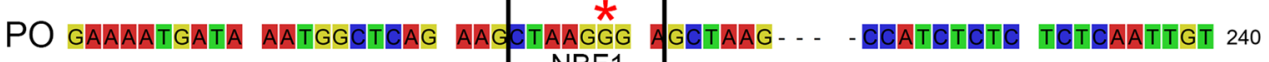
NBF1

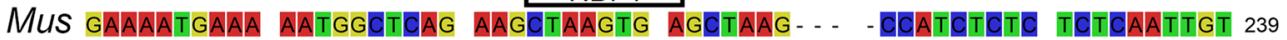

RatgaAaACGAaA AATGgCtCAG GAgCTAAGTG AgCTAAG - - - - CCATCTCTC TCTCAATTGT 243 Consensus GAAAATGAAA AATGGCTCAG AAGCTAAGTG AGCTAAG-- - - CCATCTCTC TCTCAATTGT Conservation

Fig. 2 ASH1L nucleotide conservation. a VISTA plot for Ash1l genomic loci for cow, dog, human, Mus, PO, and rat compared to BW Ashil. Blue regions indicate exons and red regions indicate conserved non-coding regions. CNS indicates a conserved non-coding sequence in intron three across all mammals analyzed. $\mathbf{b}$ DNA sequence alignment for the CNS, indicated in a for the seven mammalian species. Numbers across the top represent nucleotide locations. Conservation graph at the bottom indicates percent nucleotide conservation between the seven mammalian species. Asterisks indicate approximate locations for nucleotide differences between BW and PO. c Regional nucleotide alignment within the CNS. Asterisk indicates a single nucleotide polymorphism between BW and PO. Boxed regions indicate transcription factor binding sites in BW for NKX2.1 and in PO for NBF1

with only the PO allele. However, Sox10 is linked with Dominant spot; $46 \mathrm{~S} /+\mathrm{N}_{2}$ individuals were genotyped at the Sox10 RFLP site, and all 46 are BW/PO $\left(\chi^{2}(1, N=\right.$
46) $\left.=46, p=1.2 \times 10^{-11}\right)$. By employing the same RFLP analysis, we have identified a $1.7 \mathrm{Mb}$ region between Tex33 and Pdgfb on chromosome 20 that is linked with 
Table 4 Number of restriction enzyme recognition sites and average fragment size for $P$. maniculatus

\begin{tabular}{|c|c|c|c|}
\hline Restriction Enzyme & CpG & Number of Recognition sites in Peromyscus & Average fragment size in Peromyscus \\
\hline Apal & Yes & 384,617 & 6431 \\
\hline $\mathrm{Ascl}$ & Yes & 2460 & $1,005,504$ \\
\hline Avrll & No & 482,638 & 5125 \\
\hline BamHI & No & 410,386 & 6027 \\
\hline BspQl & No & 457,484 & 5406 \\
\hline BssHII & Yes & 115,555 & 21,405 \\
\hline Dral & No & $2,508,985$ & 986 \\
\hline Eagl & Yes & 47,415 & 52,167 \\
\hline EcoRl & No & 701,369 & 3527 \\
\hline Fsel & Yes & 13,191 & 187,517 \\
\hline HindIII & No & 809,283 & 3056 \\
\hline Nael & Yes & 105,993 & 23,336 \\
\hline Narl & Yes & 89,075 & 27,769 \\
\hline Nhel & No & 377,464 & 6553 \\
\hline Notl & Yes & 5842 & 423,406 \\
\hline Pacl & No & 146,207 & 16,918 \\
\hline Pmel & No & 34,572 & 71,547 \\
\hline Rsrll & Yes & 10,111 & 244,638 \\
\hline Sacl & No & 608,101 & 4067 \\
\hline Sacll & Yes & 47,658 & 51,901 \\
\hline Sall & Yes & 33,458 & 73,930 \\
\hline Sbfl & No & 78,368 & 31,563 \\
\hline SgrAl & Yes & 13,574 & 182,226 \\
\hline Smal & Yes & 200,696 & 12,324 \\
\hline Spel & No & 370,097 & 6683 \\
\hline Sphl & No & 654,548 & 3779 \\
\hline Sspl & No & $1,559,294$ & 1586 \\
\hline Swal & No & 166,068 & 14,894 \\
\hline Xbal & No & 748,330 & 3305 \\
\hline Xhol & Yes & 109,564 & 22,576 \\
\hline
\end{tabular}

Dominant spot (Additional File 4). Among the 53 genes contained in the linkage interval, only Sox10 has a defined role in neural crest development. Therefore, we favor the possibility that the $S$ mutation disrupts Sox 10 function. We have sequenced the Sox10 exons, exon/intron junctions, promoter, and several conserved enhancer regions but have not identified a sequence variation that disrupts Sox10 function. We are expanding the sequencing analysis to include the entire linked region.

In generating the $\mathrm{N}_{2}$ generation, we noticed that the spot size was smaller on the $F_{1}$ and $\mathrm{N}_{2}$ animals compared to the originating $\mathrm{BW}$ background. The average spot size for $25 \mathrm{~S} /+\mathrm{BW}$ animals is $77.6 \pm 36.6 \mathrm{~mm}^{2}$. We crossed one BW $S /+$ with $\mathrm{PO}+/+$ and generated six $\mathrm{F}_{1}$ $S /+$ animals, which had very small spots in comparison,
$3.75 \pm 1.56 \mathrm{~mm}^{2}$, suggesting that PO alleles have a dominant effect on the $S /+$ spot size phenotype. The six $\mathrm{F}_{1} \mathrm{~S} /+$ were backcrossed with $\mathrm{PO}+/+$ and in the $\mathrm{PO} \mathrm{N}_{2}$ generation the spot size for 46 affected animals averaged $14.5 \pm 13 \mathrm{~mm}^{2}$, which is significantly smaller than the spot size of $S /+$ BW animals (Welch's t [27] $=8.34, p=$ $5.38 \times 10^{-9}$ ), suggesting that genetic background has a significant impact on the $S /+$ phenotype. A histogram for spot size for $S /+$ on $\mathrm{BW}$ and $\mathrm{PO} \mathrm{N}_{2}$ illustrates the quantitative nature of the phenotype and the shift in spot size in the PO $\mathrm{N}_{2}$ animals (Fig. 6). We used the backcross data to estimate the number of loci that affect spot size. The six $F_{1}$ animals with small spots produced 46 offspring with spots, of which $17(37 \%)$ resembled the $F_{1}$ parent. In this backcross experiment there are only 

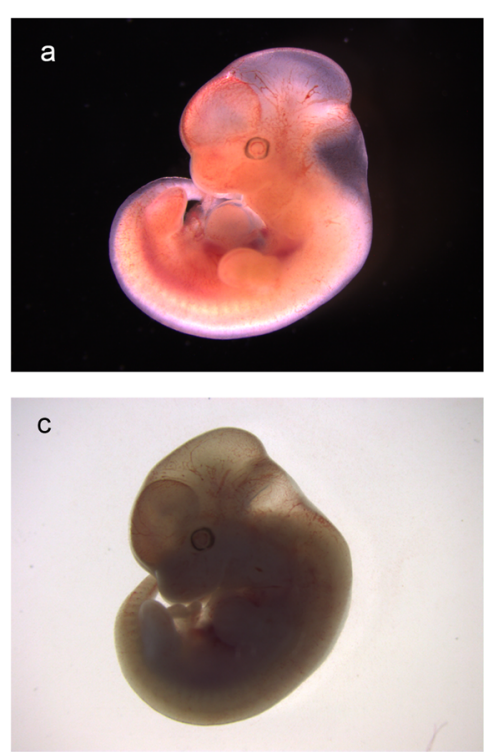

Fig. 3 Embryonic lethality of BW S/S embryos. a Wild type e14.5 embryo. b resorbing e14.5 embryo. c Wild type e13.5 embryo. d e13.5 embryo with malformations, including pericardial swelling and caudal regression. Scale bar equals $1 \mathrm{~mm}$ for all images. Images were acquired by the authors

two possible genotypes for any gene. If one unlinked locus determines the spot size phenotype, then there are two possible genotypes that interact with Dominant spot and $50 \%$ of the offspring are expected to resemble the $\mathrm{F}_{1}$ parent. If two unlinked loci determine the spot size phenotype, then $25 \%$ should resemble the parent, and if three unlinked loci are involved then $12.5 \%$ should resemble the parent. Using a $X^{2}$ analysis, we can reject a model for three interacting loci $\left(X^{2}(1, N=46)=23.19\right.$, $\left.p=1.47 \times 10^{-6}\right)$, but not models for one interacting locus $\left(X^{2}=(1, \mathrm{~N}=46)=3.13, p=0.077\right)$ or two interacting loci $\left(X^{2}(1, N=46)=2.82, p=0.093\right)$. These data suggest that there are one to two modifiers that cause the observed variability in the Dominant spot trait.
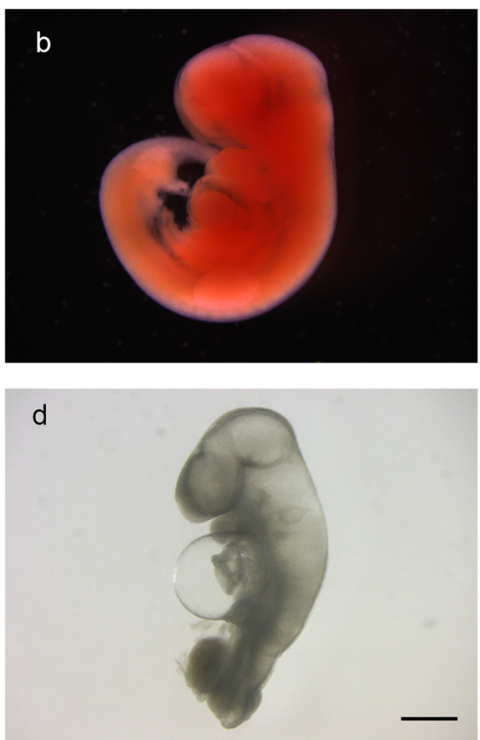

Discriminating between these two possibilities will require a larger sample size.

Further analysis indicates that there is a significant loss of affected animals in the $\mathrm{N}_{2}$ backcross. A total of 125 offspring were produced in the $\mathrm{N}_{2}$ generation. Of these animals, 46 pups had forehead spots, representing the $S /+$ genotype, while 63 are expected $\left(X^{2}(1, N=125)=\right.$ 9.25, $p=0.0024)$. Analysis of the PGSC breeding records for BW $S /+$ X BW $+/+$ indicate that the $S /+$ genotype is produced at the expected frequency (310 total offspring of which 165 have spots, $(\chi 2(1, N=310)=1.29, p=$ $0.256)$ ). These results suggest that there is a significant loss of the $S /+$ phenotype in the $\mathrm{PO} \mathrm{N}_{2}$ offspring, resulting from either a lethality of $S /+$ in $P O \mathrm{~N}_{2}$ animals or
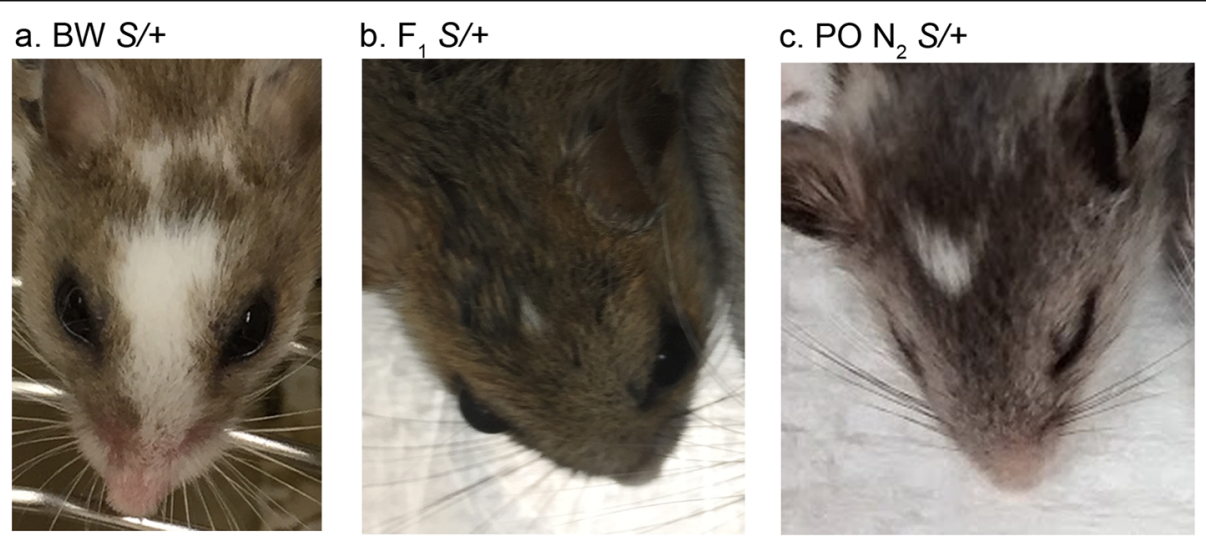

Fig. 4 Variation in spot size for the Dominant spot trait. a Large spot size on an $S /+P$. maniculatus. b Small spot size on an $S /+F_{1}$ hybrid. c Intermediate spot size on an $\mathrm{S} /+\mathrm{PO} \mathrm{N}_{2}$. Images were acquired by the authors 
Table 5 Polymorphisms that generate RFLPs between BW and PO in candidate genes that cause spotting in Mus

\begin{tabular}{|c|c|c|c|c|c|c|c|}
\hline $\begin{array}{l}\text { Candidate } \\
\text { Gene }\end{array}$ & Contig & $\begin{array}{l}\text { PCR Amplicon } \\
\text { Location }\end{array}$ & $\begin{array}{l}\text { Polymorphism } \\
\text { Location }\end{array}$ & BW sequence & $\begin{array}{l}\mathrm{PO} \\
\text { Sequence }\end{array}$ & Forward Primer & Reverse Primer \\
\hline Edn3 & $\begin{array}{l}\text { NW_ } \\
006501107\end{array}$ & $\begin{array}{l}1,645,861 \ldots 1 \\
646,386\end{array}$ & $1,646,160$ & AGGCCT (Stul) & AGTCCT & $\begin{array}{l}\text { CTCGAGAACC } \\
\text { TTGGGATTCA }\end{array}$ & $\begin{array}{l}\text { AACAGGGTCTCCTGCA } \\
\text { GTGT }\end{array}$ \\
\hline Ednrb* & $\begin{array}{l}\text { NW- } \\
006501134\end{array}$ & $\begin{array}{l}1,664,283 \ldots 1 \\
664,495\end{array}$ & $1,664,389$ & CCGG (Mspl) & CCAG & $\begin{array}{l}\text { ATGACGCCACCCAC } \\
\text { TAAGAC }\end{array}$ & $\begin{array}{l}\text { GATGATGCCTAGCA } \\
\text { CGAACA }\end{array}$ \\
\hline Kit & $\begin{array}{l}\text { NW- } \\
006501162\end{array}$ & $\begin{array}{l}6,362,706 \ldots 6 \\
363,108\end{array}$ & $\begin{array}{l}6,362,907 \ldots 6 \\
362,919\end{array}$ & $\begin{array}{l}\text { CCGTGGTACCTCTGCT } \\
\text { CGGGA (Kpnl) }\end{array}$ & $\begin{array}{l}\mathrm{CCGT//} \\
\mathrm{GGGA}\end{array}$ & $\begin{array}{l}\text { CCCGTCCTAGCTTTGG } \\
\text { AAC }\end{array}$ & $\begin{array}{l}\text { AGCATCAGGGCAACCT } \\
\text { TAAA }\end{array}$ \\
\hline Kitl & $\begin{array}{l}\text { NW_- } \\
006501158\end{array}$ & $\begin{array}{l}227,546 \ldots .228 \\
022\end{array}$ & 227,668 & GGATCC (BamHI) & GAATCC & $\begin{array}{l}\text { CCCAATTAGCTGCTCT } \\
\text { TCAAAC }\end{array}$ & $\begin{array}{l}\text { GGAGCCTTTGTGTCTT } \\
\text { ATCAGTA }\end{array}$ \\
\hline Mitf & $\begin{array}{l}N W_{-} \\
006501059\end{array}$ & $\begin{array}{l}77,663,262 \ldots 7 \\
663,281\end{array}$ & $7,663,508$ & GTATGC & $\begin{array}{l}\text { GCATGC } \\
\text { (Sphl) }\end{array}$ & $\begin{array}{l}\text { GGATGAGACTCAGG } \\
\text { GTGAGG }\end{array}$ & $\begin{array}{l}\text { GCTCCATCACTCGGCA } \\
\text { TTAT }\end{array}$ \\
\hline Pax3 & $\begin{array}{l}\text { NW_ } \\
006501055\end{array}$ & $\begin{array}{l}3,517,274 \ldots . .3 \\
517,631\end{array}$ & $3,517,515$ & TTAAA (Dral) & TTTCAA & $\begin{array}{l}\text { CCTTGCCTACTACGCT } \\
\text { CTGA }\end{array}$ & $\begin{array}{l}\text { TAATTCTGCATCCTTC } \\
\text { CGGC }\end{array}$ \\
\hline Ret & $\begin{array}{l}\text { NW_- } \\
006501668\end{array}$ & $\begin{array}{l}491,420 \ldots \text {.. 491, } \\
911\end{array}$ & 491,673 & AGGCCT (Stul) & AGACCT & $\begin{array}{l}\text { GTTCACCCTAGGAAG } \\
\text { TTGTGG }\end{array}$ & $\begin{array}{l}\text { GCCTCAGAAGCAGCCC } \\
\text { TC }\end{array}$ \\
\hline Snai2 & $\begin{array}{l}\text { NW_ } \\
006502260\end{array}$ & $\begin{array}{l}133,647 \ldots .133 \\
992\end{array}$ & 133,912 & TTTAAA (Dral) & TTTAAG & $\begin{array}{l}\text { CCAAAGTTGAAGGC } \\
\text { TGTTGC }\end{array}$ & $\begin{array}{l}\text { AGTCCATTGCTTTCAC } \\
\text { ACCT }\end{array}$ \\
\hline Sox 10 & $\begin{array}{l}\mathrm{NW}_{-} \\
006501150\end{array}$ & $\begin{array}{l}898,573 \ldots \text {.. 898, } \\
893\end{array}$ & 898,801 & CCAC & $\begin{array}{l}\text { CCGC } \\
\text { (Acil) }\end{array}$ & $\begin{array}{l}\text { GGCAGACTGAGGGA } \\
\text { GGTGTA }\end{array}$ & $\begin{array}{l}\text { GGAGATCAGC } \\
\text { CACGAGGTAA }\end{array}$ \\
\hline
\end{tabular}

* Polymorphism and primers identified by and verified in our analysis

because some $\mathrm{PO} \mathrm{N}_{2} \mathrm{~S} /+$ animals have a phenotypic rescue and do not have a forehead spot. In the backcross, PO $\mathrm{N}_{2}$ animals without spots should have two PO alleles for Sox10, barring a rare recombination event that separates the Sox10 RFLP site from the unknown causative mutation. We genotyped $50 \mathrm{PO} \mathrm{N}_{2}$ individuals without spots at the Sox10 RFLP site and found that 21 are BW/ $\mathrm{PO}$, supporting the hypothesis that a modifier can phenotypically rescue the $\mathrm{S} /+$ genotype. We are currently conducting a QTL analysis to identify loci associated with the spot size phenotype.

\section{Discussion}

In 2001 Dewey and Dawson described Peromyscus as the "Drosophila of North American Mammalogy" [43]. At the time, the nearly completed Mus and human genome projects suggested that less traditional model systems would benefit from the application of the rich genetic resources provided by the completed Mus and human genomes. They believed that the increase in genomic resources would enable Peromyscus geneticists to identify the loci associated with specific behaviors and physiological traits associated with specific species or subspecies of Peromyscus. They were correct. The ability to generate fertile hybrids of $P$. maniculatus and $P$. polionotus coupled with QTL analysis has led to the identification of many loci associated with specific behaviors, such as burrow building and paternal parenting $[15,16]$. The recent generation of genomic assemblies for $P$. maniculatus, $P$. polionotus, and P. leucopus should only quicken the pace of discovery [21].
To facilitate the use of Peromyscus for gene discovery, we have used available genomic resources to identify polymorphisms between $P$. maniculatus and $P$. polionotus. Our conservative estimate demonstrates that these closely related species have a polymorphism approximately every 68 base pairs. This genetic diversity supports the use these species for QTL analysis, as the sequence variation prevents large blocks of linkage disequilibrium, a characteristic that has been problematic for QTL analysis in Mus [4]. Most of the sequence variation occurs in intergenic or intronic regions; however, more than 10,000 genes have a polymorphism that results in a missense or nonsense variation between the two species, which could result in a functional difference between the $P$. maniculatus and $P$. polionotus alleles. GO term analysis on this list of proteins results in over 2000 GO terms that are overrepresented. This list is not necessarily informative based on the descriptive nature of GO terms at the top of the list, such as cellular or metabolic process, but it is more meaningful when used in combination with known physiological or behavioral differences between the species. P. polionotus have a 2fold increase in blood triglycerides compared to P. maniculatus [24], and there are 62 genes associated with GO terms related to triglyceride metabolism. This selection of triglyceride associated genes provides a potential candidate gene list for identifying genetic variations associated with varying triglyceride levels. All these genes have human homologues, suggesting that variations identified in Peromyscus may inform human genetic variability associated with triglyceride levels. 


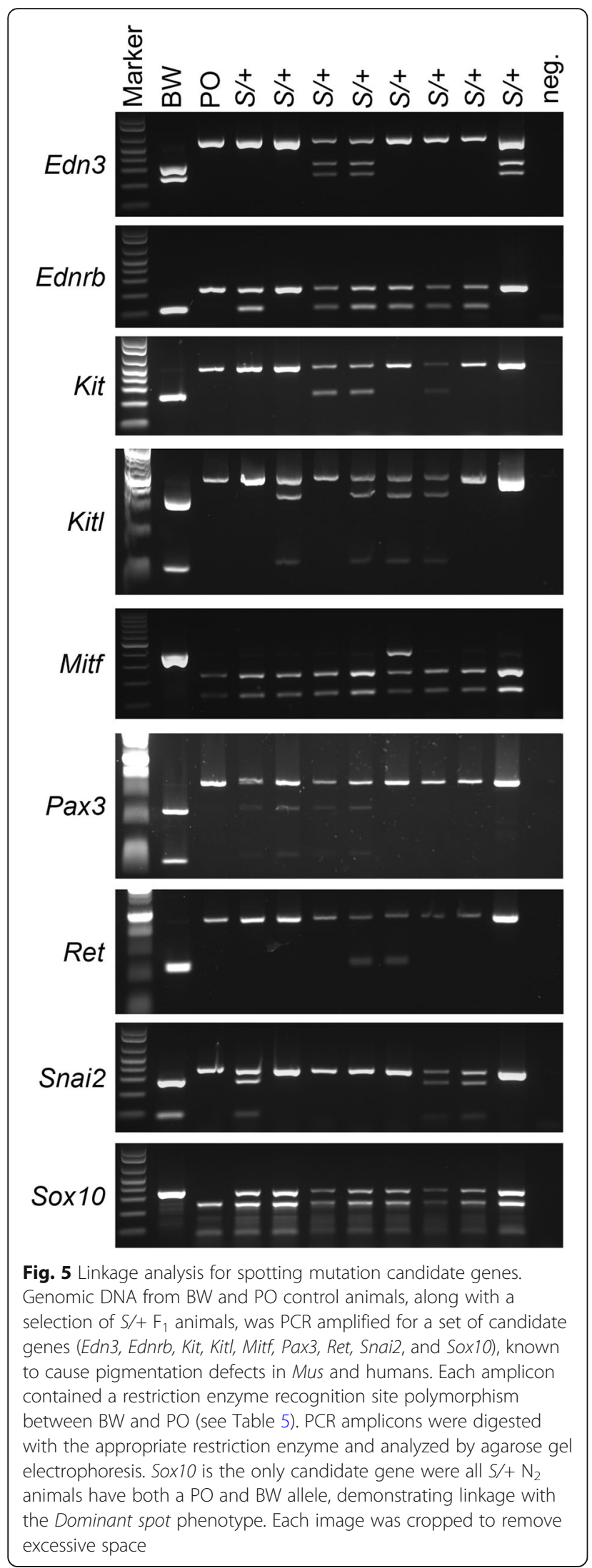

The list of triglycerides associated candidate genes is a conservative estimate based on the possibility of protein functional changes. The number of genes is likely much higher, as changes in regulatory regions that affect transcriptional levels are also possible. We demonstrated the potential for polymorphisms affecting transcription by analyzing the $\mathrm{CNS}$ for $\mathrm{ASH} 1 \mathrm{~L}$, an autism candidate gene [34]. We show that non-coding polymorphisms change predicted transcription factor binding sites for NKX2-1 and EBF1 in the ASH1L CNS. Mutations in NKX2-1 cause benign hereditary chorea and have recently been associated with autism [44]. $N k x 2-1$ is expressed in the medial ganglionic eminence (MGE) and is critical for the production of inhibitory gamma amino butyric acid (GABA)eric cortical interneurons [45]. Reductions in these inhibitory neurons are associated with autism [46]. Common genetic variations in EBF1 have also been associated with premature birth and autism [47]. Ebf1 is expressed in the lateral ganglionic eminence (LGE), which generates striatal projection neurons, including medium spiny neurons that are preferential lost in Huntington's disease [48, 49]. Ebf1 is essential for striatum formation and the generation of direct striatal projection neurons that project to the substantia nigra [50, 51]. Functional experiments are necessary to determine the potential impact of this and other non-coding polymorphisms on ASH1L transcription. Our comparative approach for both protein and DNA conservation demonstrates that the variations between $\mathrm{BW}$ and $\mathrm{PO}$ provides a rich source for functional analysis. Future QTL analysis between $P$. maniculatus and $P$. polionotus may help to narrow these candidate gene lists to identify genes that underlie the phenotypic difference between these species. Doing so will provide an animal model that will correlate genotypic variability with autism like behaviors. In addition, Peromyscus is an excellent model system for testing of future therapeutics, as the outbred nature of the stock will better model the variability of the human population than inbred Mus lines.

We combined linkage analysis, using $P$. maniculatus and $P$. polionotus, the polymorphisms between the two species, and a candidate gene approach to link the Dominant spot trait with Sox10. Mutations in Sox10 are known to cause belly spotting and megacolon in Mus and Waardenburg syndrome, types $2 \mathrm{E}$ and $4 \mathrm{C}$ in humans [52-54]. Waardenburg syndrome is genetically heterogeneous and results from mutations in Sox10, Pax3, Mitf, Snai2, Ednrb, and Edn3, as well as many cases with unidentified mutations [55]. The phenotypic presentation of Waardenburg syndrome is variable, even in families with the same mutation, suggesting that there are genetic modifiers that affect the severity of the phenotype [56-58]. We see similar phenotypic variability in Dominant spot. P. maniculatus with the Dominant 


\section{Histogram of S/+ Spot Size}

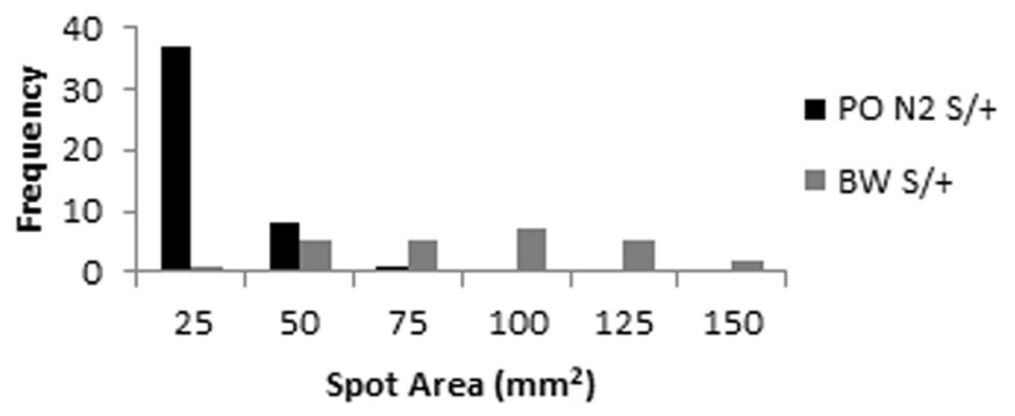

Fig. 6 Histogram of spot size variation. This histogram displays the frequency of spot size area $\left(\mathrm{mm}^{2}\right)$ for 25 BW S/+ (gray) and $46 \mathrm{~S} /+$ on PO $\mathrm{N}_{2}$ (black)

spot trait have a variable forehead spot size, tending towards larger spots. Dominant spot on the $\mathrm{PO} \mathrm{N}_{2}$ background have significantly smaller spots. We believe that there are likely one to two genetic modifiers that interact with Dominant spot to cause the variability in spot size. Intriguingly, the Dominant spot trait is underrepresented on the $\mathrm{PO} \mathrm{N}_{2}$ background, and likely results from a gene interaction that rescues the Dominant spot phenotype. A QTL analysis to identify loci associated with spot size variability is underway and may identify novel members of the neural crest developmental gene regulatory network (GRN) or novel alleles of known members of the GRN, which could expand our understanding of neural crest and melanocyte development. In addition to Dominant spot, the PGSC maintains the Variable white and Tan streak stocks, which also have pigmentation defects that are likely caused by mutations in the neural crest GRN [59, 60]. The improved genomic resources for Peromyscus combined with the three stocks of $P$. maniculatus with pigmentation defects and the inherent variability found in these outbred stocks makes Peromyscus an excellent model system for studying neural crest biology.

\section{Conclusions}

The availability of genomic resources for $P$. maniculatus and $P$. polionotus facilitates the use of these rodent species to identify genomic loci associated with quantitative traits. We have conducted a linkage analysis for the Dominant spot trait, which arose in $P$. maniculatus by crossing it with $P$. polionotus. Using available genomic information, we identified RFLP polymorphisms between the two species in a set of candidate genes associated with pigmentation disruptions in Mus and humans and determined that a region of chromosome 20 containing Sox10 is linked with the Dominant spot trait. Further analysis of the available genomic data demonstrates that there is significant genetic complexity between $P$. maniculatus and $P$. polionotus that underlies both physiological and behavior differences, including blood chemistry and stereotypic behaviors. QTL analysis for these traits will provide correlated loci that will aid in the identification of functional polymorphisms that generate phenotypic differences.

\section{Methods \\ Polymorphism analysis}

The first genomic assembly of the P. maniculatus genome, National Center for Biotechnology Information (NCBI) accession number GCF_000500345.1, was locally downloaded and used as the reference genome. Whole genome sequence reads, NCBI accession numbers SRX179420, SRX179421, and SRX179422, for P. polionotus were downloaded from the SRA database. After these sequences were converted into FASTQ format using the SRA Tool Kit (v. 2.1.16 centOS Linux 64-bit), the sequence reads, SRX179420 and SRX179422, which contained paired-end sequences reads, were split into two files, using Python script. The forward and reverse paired-end reads were linked to each other and the indexed adapter sequences were trimmed, using the Solexa QA package v. 1.13 [61]. End sequences were trimmed when the Phred quality score dropped below $\mathrm{Q}=20$. Trimmed $\mathrm{PO}$ sequence reads were aligned to the reference genome sequence, using the Burrows-Wheeler Aligner (BWA) program (v. 0.6.1-r104) [62]. The BWA default values for mapping were used, except that seed length $(-1)$ was set to 28 and maximum differences in the seed $(-\mathrm{k})$ equaled 1 . Following alignment to the reference genome, data from each $P$. polionotus dataset was merged into one file. Sequence polymorphisms between the aligned $P$. polionotus sequence reads and the $P$. maniculatus reference genome were identified using the pileup function in SAMtools utilities (v. 0.1.16) [63]. The 
minimum read depth was set to 10 and the consensus sequence was generated with filter command "-uf". SnpEff was utilized, using default parameters, to identify possible functional consequences of the SNP/Indel variant list produced from BCFtools. Data files for the sequence polymorphisms and annotations are available as .vcf files at https://osf.io/4eypx/.

$\mathrm{GO}$ analysis was performed on the list of genes containing nonsynonymous changes, as determined above. This list was compared to the Mus GO term database using the R packages Gostats [64] to identify highly statistically significant over and underrepresented $\mathrm{GO}$ terms with a $p<0.001$.

ASH1L protein alignments were performed using CLC Main Workbench 8 (Qiagen). Protein sequences for human (NCBI accession number NP_060959.2), dog (NCBI accession number XP_537251.2), cow (NCBI accession number NP_001179672.1), Mus (NCBI accession number NP_619620.3), and rat (NCBI accession number NP_001101159.1) were imported into CLC Main Workbench from NCBI. Predicted BW ASH1L protein sequence was generated from the $P$. maniculatus reference genome (NCBI accession number GCF_000500345.1 and GeneID 102,924,929) and the P. polionotus protein sequence was generated from the $P$. maniculatus sequence with predicted nonsynonymous substitutions based on our polymorphism analysis.

The VISTA plot was generated using the mVISTA tool on the VISTA Gateway, http://genome.lbl.gov/vista/index. shtml $[35,65]$. Sequences and annotations were downloaded from Ensembl, www.ensembl.org: cow chromosome 3:15111790-15,300,435 (NCBI accession number GCF_002263795.1); dog chromosome 7:42049263-42,231, 760 (NCBI accession number GCF_000002285.3); human chromosome 1:155319268-155,568,307 (NCBI accession number GCF_000001405.39); Mus chromosome 3: 92474023-92,630,085 (NCBI accession number GCA 001632555.1); and rat chromosome 2:188243220-188,391, 250 (NCBI accession number GCF_000001895.5). Peromyscus sequences were from $P$. maniculatus scaffold NW_006501110:3142128-3,299,387 (NCBI accession number GCF_000500345.1) and P. polionotus chromosome 6:67063888-67,238,298 (NCBI accession number GCA_003704135.2).

Alignment of the conserved non-coding sequences in intron 3 was performed in CLC Main Workbench 8 with the following sequences: $P$. maniculatus scaffold NW 006501110:3241913-3,242,512; cow chromosome 3: 15170453-15,171,101; dog chromosome 7:42120548-42, 121,199; human chromosome 1:155462242-155,462,894; Mus chromosome 3:92529139-92,529,730; P. polionotus chromosome 6:67134871-67,135,471; and rat chromosome 2:188298601-188,299,194. Transcription factor binding site analysis was conducted using PROMO, http://alggen.lsi.upc.es/, using Mus transcription factors and binding sites with the $P$. maniculatus sequence NW_006501110:3242286-3,242,313 and P. polionotus sequence 6:67135070-67,135,097 [37, 38].

For restriction enzyme recognition site frequency analysis, the number of restriction enzyme recognition sites and average fragment length for each enzyme was calculated using the R package DECIPHER v2.0 using the $P$. maniculatus genome assembly (NCBI accession number GCF_000500345.1) [66].

\section{Peromyscus}

All animal research was approved by the UofSC Institutional Animal Care and Use Committee. All animals used in this study were euthanized by $\mathrm{CO}_{2}$ asphyxiation, which is an American Veterinary Medical Association approved methodology for euthanasia for small rodents. Dominant spot P. maniculatus $(S /+)$ on the BW laboratory stock and PO laboratory stock $P$. polionotus were obtained from the PGSC, https://www.pgsc.cas.sc.edu, and housed in solid-bottom opaque plastic cages with a wire bar lid, which serves as a food hopper and water bottle holder, and a filter top. Animals were group housed by sex, with up to six animals per cage, and provided paper-product bedding and nesting material. Peromyscus were housed with a 16 to 8 -h light to dark cycle and feed food and water ad libitum. Matings were between one male and one female and pups were weaned at postnatal day 24. To generate timed pregnancies, Dominant spot $(\mathrm{S} /+)$ BW females and males were paired together. The following morning phosphate buffered saline, $\mathrm{pH} 7.3$ (PBS) was used for a vaginal lavage on the females, and the wash checked for the presence of sperm. The presence of sperm was used to indicate pregnancy and noon of the day the sperm was detected was designated as e0.5. Embryos were collected on e13.5 and e14.5, photographed, and fixed in $4 \%$ paraformaldehyde in PBS overnight at $4 \mathrm{C}$. After fixation, embryos were washed in PBS and dehydrated into $70 \%$ ethanol for storage at $-20 \mathrm{C}$.

Using Mus linkage analysis as a guide, genotyping 50 mice can demonstrate linkage within 2 centiMorgans with $95 \%$ confidence [67]. Therefore, we set a goal of generating approximately 50 Dominant spot animals in a backcross experiment. One $S /+$ BW female was mated with a $+/+\mathrm{PO}$ male to generate an $\mathrm{F}_{1}$ generation. Six $\mathrm{F}_{1}$ $S /+$ offspring with forehead spots (the Dominant spot trait) were then backcrossed to $+/+$ PO animals to generate a $\mathrm{PO} \mathrm{N}_{2}$ generation with 125 individuals. Both male and female $\mathrm{N}_{2}$ offspring were euthanized at weaning, photographed to document the spotting phenotype, and tail snips taken for genotyping. Within the $\mathrm{N}_{2}$ generation 46 animals had the Dominant spot trait and 79 were wild type. Photographs of forehead spots of 25 
Dominant spot $\mathrm{BW}$ and 46 Dominant spot $\mathrm{PO} \mathrm{N}_{2}$ were analyzed to determine the area of white fur, using the Fiji distribution of ImageJ [68]. The total number of animals used for all experiments, including the three generations of the backcross experiment and the timed pregnancies was 143.

PCR genotyping was performed for a set of neural crest candidate genes, using primers listed in Table 5, in a $25 \mu \mathrm{l}$ reaction with a $63^{\circ} \mathrm{C}$ annealing temperature for 30 cycles, using Dream Taq and Dream Taq Green Buffer (Thermo Fisher Scientific). The PCR amplicon was designed to contain a restriction enzyme recognition site in either the BW or PO allele of the candidate gene (see below for restriction enzyme selection). $0.5 \mu \mathrm{l}$ of the appropriate restriction enzyme was added directly to the PCR mix and incubated at $37^{\circ} \mathrm{C}$ for at least $2 \mathrm{~h}$, before agarose gel electrophoresis on a $1.5 \%$ agarose gel. Images of Peromyscus, embryos, and electrophoretic gels were adjusted for brightness across the entire image, cropped to remove excessive space, and labels added using Adobe Photoshop.

\section{Supplementary information}

Supplementary information accompanies this paper at https://doi.org/10. 1186/s12864-020-06969-1.

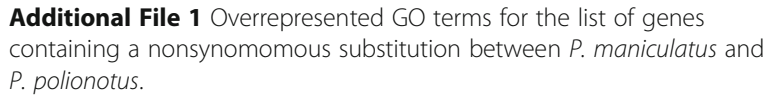

Additional File 2 Underrepresented GO terms for the list of genes containing a nonsynomomous substitution between $P$. maniculatus and P. polionotus.

Additional File 3. Electrophoresis gel images before cropping used for Fig. 5.

Additional File 4 Electrophoresis gel images for linkage analysis of Tex33 and Pdgfb.

\section{Abbreviations \\ BW: Laboratory stock of P. maniculatus; BWA: Burrows-Wheeler Aligner; CNS: Conserved non-coding sequences; ddRADseq: Double digest RADseq; INDELs: Insertions or deletions; GABA: Gamma amino butyric acid; GO: Gene ontology; GRN: Gene regulatory network; GWAS: Genome wide association studies; NCBI: National Center for Biotechnology Information; LL: Laboratory stock of P. leucopus; LGE: Lateral ganglionic eminence; MGE: Medial ganglionic eminence; PCR: Polymerase chain reaction; PGSC: Peromyscus Genetic Stock Center; PO: Laboratory stock of P. polionotus; QTL: Quantitative trait loci; RADseq: Restriction site-associated DNA sequencing; RE: Restriction enzyme; RFLP: Restriction fragment length polymorphisms; SFARI: Simons Foundation Autism Research Initiative; SI: Similarity index; SNP: Single nucleotide polymorphisms; SRA: Sequencing Read Archive; UofSC: University of South Carolina; UTR: Untranslated region}

\section{Acknowledgements}

We wish to thank the Peromyscus Genetic Stock Center, its director Hippokratis Kiaris, and colony managers Vimala Kaza and Janet Crossland for maintaining the Dominant spot stock.

\section{Author contributions}

SWD designed and conducted experiments, analyzed and interpreted data, and drafted and revised the manuscript. ZS, DJH, RHM, and JLK designed and conducted experiments, analyzed and interpreted data, and revised the manuscript. MRF analyzed and interpreted data and revised the manuscript. All authors have read and approved the manuscript.

\section{Authors' information}

$\mathrm{ZS}$ is a graduate student, RHM and JKL were undergraduate researchers, JLK was a laboratory technician, MRF is a Professor Emeritus, and SWD is an Associate Professor in the Department of Biological Sciences at the University of South Carolina.

\section{Funding}

Funding was provided by startup funding to SWD from University of South Carolina, a National Institutes of Health grant, 1R03DE028371 (SWD Principle Investigator), and a National Science Foundation EPSCoR grant, OIA-1736150 (SWD Senior Personnel). Funding agencies did not influence the design of this study, the analysis or interpretation of data, or writing of this manuscript.

\section{Availability of data and materials}

Most of the data generated or analyzed during this study are included in this published article and its supplementary information files. The remaining datasets generated and/or analyzed during the current study are available at the following sources: the polymorphisms between $P$. maniculatus and $P$. polionotus and their functional annotations are located on the Open Science Framework repository of the Center for Open Science, https://osf.io/4eypx/ and DOI: https://doi.org/10.17605/OSF.IO/4EYPX. The National Center for Biotechnology Information (NCBI), https://www.ncbi.nlm.nih.gov/, stores many sequences analyzed in this studying, including $P$. maniculatus reference genome, GCF_000500345.1, https://www.ncbi.nlm.nih.gov/ assembly/GCA_000500345.1. The P. polionotus sequence reads are available in the Sequence Read Archive (SRA) at NCBI, https://www.ncbi.nlm.nih.gov/ sra, specifically SRX179420, https://www.ncbi.nlm.nih.gov/sra/SRX17942 0[accn], SRX179421, https://www.ncbi.nlm.nih.gov/sra/SRX179421[accn], and SRX179422 https://www.ncbi.nlm.nih.gov/sra/SRX179422[accn]. ASHIL protein sequences are available at NCBI, including human NP_060959.2, https:// www.ncbi.nlm.nih.gov/protein/NP_060959.2/, dog XP_537251.2, https://www. ncbi.nlm.nih.gov/protein/XP_537251.2, cow NP_001179672.1, https://www. ncbi.nlm.nih.gov/protein/NP_001179672.1, Mus NP_619620.3 https://www. ncbi.nlm.nih.gov/protein/NP_619620.3, rat NP_001101159.1 https://www.ncbi. nlm.nih.gov/protein/NP_001101159.1, and P. maniculatus https://www.ncbi. nlm.nih.gov/gene/?term=102924929\%5BUID\%5D. The sequences and annotations used for the VISTA plot are available from Ensembl, https:// useast.ensembl.org/, including cow chromosome 3:15111790-15300435, https://useast.ensembl.org/Bos_taurus/Gene/Summary? db=core; $g=$ ENSBTAG00000003954;r=3:15121790-15298435, dog chromosome 7:42049263-42231760, https://useast.ensembl.org/Canis_lupus_familiaris/ Gene/Summary?db=core;g=ENSCAFG00000016944; $r=7: 42046569-42225456 ; t=$ ENSCAFT00000026816, human chromosome 1:155319268-155568307, https://useast.ensembl.org/Homo_sapiens/Gene/Summary?db=core;g= ENSG000001 16539; $r=1: 155335268-155562807$, Mus chromosome 3:9247402392630085, https://useast.ensembl.org/Mus_musculus/Gene/Summary?db= core;g=ENSMUSG00000028053;r=3:88950622-89079375, and rat chromosome 2:188243220-188391250, https://useast.ensembl.org/Rattus_norvegicus/ Gene/Summary?db=core; $\mathrm{g}=$ ENSRNOG00000020386; $\mathrm{r}=2: 188253220-18838925$ 0 . Peromyscus sequences for the VISTA plot are available at NCBI, including $P$. maniculatus scaffold NW_006501110:3142128-3299387, https://www.ncbi. nlm.nih.gov/nuccore/NW_006501110.1/, and P. polionotus chromosome 6:67063888-67238298, https://www.ncbi.nlm.nih.gov/nuccore/CM010908.1.

\section{Ethics approval and consent to participate}

This research did not use human subjects or data. All animal research was approved by UofSC Institutional Animal Care and Use Committee. The animal care and use program at UofSC is accredited by the Association for Assessment and Accreditation of Laboratory Animal Care International (AAAL AC), is registered as a research facility with the United States Department of Agriculture (USDA), and holds an approved Assurance of Compliance from the Public Health Service's Office of Laboratory Animal Welfare (OLAW).

\section{Consent for publication}

No human subjects were used in this research; therefore, a consent for publication is not applicable. 


\section{Competing interests}

The authors declare that they have no competing interests.

\section{Received: 6 February 2020 Accepted: 3 August 2020 Published online: 11 September 2020}

\section{References}

1. Vrana PB, Shorter KR, Szalai G, Felder MR, Crossland JP, Veres M, et al. Peromyscus (deer mice) as developmental models. Wiley interdiscip Rev Dev Biol. 2014;3(3):211-30.

2. Steppan S, Adkins R, Anderson J. Phylogeny and divergence-date estimates of rapid radiations in muroid rodents based on multiple nuclear genes. Syst Biol. 2004;53(4):533-53.

3. Yang $H$, Wang JR, Didion JP, Buus RJ, Bell TA, Welsh CE, et al. Subspecific origin and haplotype diversity in the laboratory mouse. Nat Genet. 2011 43(7):648-55.

4. Flint J, Eskin E. Genome-wide association studies in mice. Nat Rev Genet. 2012;13(11):807-17.

5. Collaborative Cross $C$. The genome architecture of the Collaborative cross mouse genetic reference population. Genetics. 2012;190(2):389-401.

6. Saul MC, Philip VM, Reinholdt LG. Center for Systems Neurogenetics of a, Chesler EJ. High-diversity mouse populations for complex traits. Trends Genet. 2019;35(7):501-14

7. Churchill GA, Gatti DM, Munger SC, Svenson KL. The diversity outbred mouse population. Mamm Genome. 2012;23(9-10):713-8.

8. Svenson KL, Gatti DM, Valdar W, Welsh CE, Cheng R, Chesler EJ, et al. Highresolution genetic mapping using the mouse diversity outbred population. Genetics. 2012;190(2):437-47.

9. Shorter JR, Huang W, Beak JY, Hua K, Gatti DM, de Villena FP, et al. Quantitative trait mapping in diversity outbred mice identifies two genomic regions associated with heart size. Mamm Genome. 2018;29(1-2):80-9.

10. Yalcin B, Nicod J, Bhomra A, Davidson S, Cleak J, Farinelli L, et al. Commercially available outbred mice for genome-wide association studies. PLoS Genet. 2010;6(9):e1001085.

11. Joyner CP, Myrick LC, Crossland JP, Dawson WD. Deer mice as laboratory animals. ILAR J. 1998;39(4):322-30.

12. Bedford NL, Hoekstra HE. Peromyscus mice as a model for studying natural variation. eLife. 2015;4

13. Havighorst A, Zhang Y, Farmaki E, Kaza V, Chatzistamou I, Kiaris H. Differential regulation of the unfolded protein response in outbred deer mice and susceptibility to metabolic disease. Dis Model Mech. 2019:12(2).

14. Munshi-South J, Richardson JL. Peromyscus transcriptomics: understanding adaptation and gene expression plasticity within and between species of deer mice. Semin Cell Dev Biol. 2017:61:131-9.

15. Bendesky A, Kwon YM, Lassance JM, Lewarch CL, Yao S, Peterson BK, et al. The genetic basis of parental care evolution in monogamous mice. Nature. 2017;544(7651):434-9.

16. Weber JN, Peterson BK, Hoekstra HE. Discrete genetic modules are responsible for complex burrow evolution in Peromyscus mice. Nature. 2013:493(7432):402-5.

17. Linnen CR, Poh YP, Peterson BK, Barrett RD, Larson JG, Jensen JD, et al. Adaptive evolution of multiple traits through multiple mutations at a single gene. Science. 2013;339(6125):1312-6.

18. Shorter KR, Owen A, Anderson V, Hall-South AC, Hayford S, Cakora P, et al. Natural genetic variation underlying differences in Peromyscus repetitive and social/aggressive behaviors. Behav Genet. 2014;44(2):126-35.

19. Wolmarans W, Scheepers IM, Stein DJ, Harvey BH. Peromyscus maniculatus bairdii as a naturalistic mammalian model of obsessive-compulsive disorder: current status and future challenges. Metab Brain Dis. 2018;33(2):443-55.

20. Jiujias M, Kelley E, Hall L. Restricted, repetitive behaviors in autism Spectrum disorder and obsessive-compulsive disorder: a comparative review. Child Psychiatry Hum Dev. 2017:48(6):944-59.

21. Long AD, Baldwin-Brown J, Tao Y, Cook VJ, Balderrama-Gutierrez G, CorbettDetig R, et al. The genome of Peromyscus leucopus, natural host for Lyme disease and other emerging infections. Sci Adv. 2019;5(7):eaaw6441.

22. Peterson BK, Weber JN, Kay EH, Fisher HS, Hoekstra HE. Double digest RADseq: an inexpensive method for de novo SNP discovery and genotyping in model and non-model species. PLoS One. 2012;7(5):e37135.

23. Baird NA, Etter PD, Atwood TS, Currey MC, Shiver AL, Lewis ZA, et al. Rapid SNP discovery and genetic mapping using sequenced RAD markers. PLoS One. 2008;3(10):e3376
24. Wiedmeyer CE, Crossland JP, Veres M, Dewey MJ, Felder MR, Barlow SC, et al. Hematologic and serum biochemical values of 4 species of Peromyscus mice and their hybrids. J Am Assoc Lab Anim Sci. 2014;53(4): $336-43$

25. Baumgardner DJ, Ward SE, Dewsbury DA. Diurnal patterning of 8 activities in 14 species of Muroid rodents. Anim Learn Behav. 1980;8(2):322-30.

26. Powell SB, Newman HA, Pendergast JF, Lewis MH. A rodent model of spontaneous stereotypy: initial characterization of developmental, environmental, and neurobiological factors. Physiol Behav. 1999;66(2): 355-63.

27. Katherine M. Stereotypic Movement Disorders. Semin Pediatr Neurol. 2018; 25:19-24.

28. Lewis MH. Environmental complexity and central nervous system development and function. Ment Retard Dev Disabil Res Rev. 2004;10(2): 91-5.

29. Presti MF, Mikes HM, Lewis MH. Selective blockade of spontaneous motor stereotypy via intrastriatal pharmacological manipulation. Pharmacol Biochem Behav. 2003;74(4):833-9.

30. Battle DE. Diagnostic and statistical manual of mental disorders (DSM). Codas. 2013;25(2):191-2.

31. Gregory GD, Vakoc CR, Rozovskaia T, Zheng X, Patel S, Nakamura $T$, et al. Mammalian ASH1L is a histone methyltransferase that occupies the transcribed region of active genes. Mol Cell Biol. 2007;27(24):8466-79.

32. Wang $T$, Guo H, Xiong B, Stessman HA, Wu H, Coe BP, et al. De novo genic mutations among a Chinese autism spectrum disorder cohort. Nat Commun. 2016:7:13316.

33. Tammimies K, Marshall CR, Walker S, Kaur G, Thiruvahindrapuram B, Lione AC, et al. Molecular diagnostic yield of chromosomal microarray analysis and whole-exome sequencing in children with autism Spectrum disorder. JAMA. 2015:314(9):895-903.

34. De Rubeis S, He X, Goldberg AP, Poultney CS, Samocha K, Cicek AE, et al. Synaptic, transcriptional and chromatin genes disrupted in autism. Nature. 2014;515(7526):209-15.

35. Frazer KA, Pachter L, Poliakov A, Rubin EM, Dubchak I. VISTA: computational tools for comparative genomics. Nucleic Acids Res. 2004;32(Web Server issue):W273-9.

36. Kent WJ, Sugnet CW, Furey TS, Roskin KM, Pringle TH, Zahler AM, et al. The human genome browser at UCSC. Genome Res. 2002:12(6):996-1006.

37. Messeguer X, Escudero R, Farre D, Nunez O, Martinez J, Alba MM. PROMO: detection of known transcription regulatory elements using species-tailored searches. Bioinformatics. 2002;18(2):333-4.

38. Farre D, Roset R, Huerta M, Adsuara JE, Rosello L, Alba MM, et al. Identification of patterns in biological sequences at the ALGGEN server: PROMO and MALGEN. Nucleic Acids Res. 2003;31(13):3651-3.

39. Davey JW, Blaxter ML. RADSeq: next-generation population genetics. Brief Funct Genomics. 2010;9(5-6):416-23.

40. Feldman HW. Piebald characters of the deer mouse. J Heredity. 1936;27(8):301.

41. Dawson WD. Fertility and size inheritance in a Peromyscus species cross Evol Int J Organic Evol. 1965:19(1):44-55.

42. Hou L, Pavan WJ. Transcriptional and signaling regulation in neural crest stem cell-derived melanocyte development: do all roads lead to Mitf? Cell Res. 2008;18(12):1163-76.

43. Dewey MJ, Dawson WD. Deer mice: "the Drosophila of north American mammalogy". Genesis. 2001;29(3):105-9.

44. Milone R, Masson R, Di Cosmo C, Tonacchera M, Bertini V, Guzzetta A, et al. A Not So Benign Family Pedigree With Hereditary Chorea: A Broader Phenotypic Expression or Additional Picture? Child Neurol Open. 2019;6: $2329048 \times 19828881$.

45. Sussel L, Marin O, Kimura S, Rubenstein JLR. Loss of Nkx2.1 homeobox gene function results in a ventral to dorsal molecular respecification within the basal telencephalon: evidence for a transformation of the pallidum into the striatum. Development. 1999:126(15):3359-70.

46. Hashemi E, Ariza J, Rogers H, Noctor SC, Martínez-Cerdeño V. The number of Parvalbumin-expressing interneurons is decreased in the prefrontal cortex in autism. Cereb Cortex. 2017;27(3):1931-43.

47. Sajdel-Sulkowska EM, Makowska-Zubrycka M, Czarzasta K, Kasarello K, Aggarwal $V$, Bialy $M$, et al. Common genetic variants link the abnormalities in the gutbrain Axis in prematurity and autism. Cerebellum. 2019:18(2):255-65.

48. Corbin JG, Rutlin M, Gaiano N, Fishell G. Combinatorial function of the homeodomain proteins Nkx2.1 and Gsh2 in ventral telencephalic patterning. Development. 2003;130(20):4895-906. 
49. Reiner A, Albin RL, Anderson KD, D'Amato CJ, Penney JB, Young AB. Differential loss of striatal projection neurons in Huntington disease. Proc Natl Acad Sci U S A. 1988;85(15):5733-7.

50. Garel S, Marin F, Grosschedl R, Charnay P. Ebf1 controls early cell differentiation in the embryonic striatum. Development. 1999;126(23):528594.

51. Tinterri A, Menardy F, Diana MA, Lokmane L, Keita M, Coulpier F, et al. Active intermixing of indirect and direct neurons builds the striatal mosaic. Nat Commun. 2018;9(1):4725.

52. Herbarth B, Pingault V, Bondurand N, Kuhlbrodt K, Hermans-Borgmeyer I, Puliti A, et al. Mutation of the Sry-related Sox10 gene in dominant megacolon, a mouse model for human Hirschsprung disease. Proc Natl Acad Sci U S A. 1998;95(9):5161-5.

53. Pingault V, Bondurand N, Kuhlbrodt K, Goerich DE, Prehu MO, Puliti A, et al. SOX10 mutations in patients with Waardenburg-Hirschsprung disease. Nat Genet. 1998;18(2):171-3.

54. Bondurand N, Dastot-Le Moal F, Stanchina L, Collot N, Baral V, Marlin S, et al. Deletions at the SOX10 gene locus cause Waardenburg syndrome types 2 and 4. Am J Hum Genet. 2007;81(6):1169-85.

55. Pingault V, Ente D, Dastot-Le Moal F, Goossens M, Marlin S, Bondurand N. Review and update of mutations causing Waardenburg syndrome. Hum Mutat. 2010:31(4):391-406.

56. Baldwin $C T$, Hoth CF, Macina RA, Milunsky A. Mutations in PAX3 that cause Waardenburg syndrome type I: ten new mutations and review of the literature. Am J Med Genet. 1995;58(2):115-22.

57. Jelena B, Christina L, Eric V, Fabiola QR. Phenotypic variability in Waardenburg syndrome resulting from a 22q12.3-q13.1 microdeletion involving SOX10. Am J Med Genet A. 2014;164A(6):1512-9.

58. Edery P, Pelet A, Mulligan $L M$, Abel L, Attie $T$, Dow E, et al. Long segment and short segment familial Hirschsprung's disease: variable clinical expression at the RET locus. J Med Genet. 1994;31(8):602-6.

59. Wang LR, Crossland JP, Dawson WD. Coat color genetics of Peromyscus: II. Tan streak--a new recessive mutation in the deer mouse, P. maniculatus. J Heredity. 1993;84(4):304-6.

60. Cowling K, Robbins RJ, Haigh GR, Teed SK, Dawson WD. Coat color genetics of Peromyscus: IV. Variable white, a new dominant mutation in the deer mouse. J Heredity. 1994;85(1):48-52

61. Cox MP, Peterson DA, Biggs PJ. SolexaQA: at-a-glance quality assessment of Illumina second-generation sequencing data. BMC Bioinform. 2010;11:485.

62. Li H, Durbin R. Fast and accurate short read alignment with burrowswheeler transform. Bioinformatics. 2009;25(14):1754-60.

63. Li H, Handsaker B, Wysoker A, Fennell T, Ruan J, Homer N, et al. The sequence alignment/map format and SAMtools. Bioinformatics. 2009;25(16): 2078-9.

64. Falcon S, Gentleman R. Using GOstats to test gene lists for $\mathrm{GO}$ term association. Bioinformatics. 2007;23(2):257-8.

65. Mayor C, Brudno M, Schwartz JR, Poliakov A, Rubin EM, Frazer KA, et al. VISTA : visualizing global DNA sequence alignments of arbitrary length. Bioinformatics. 2000;16(11):1046-7.

66. Wright ES. Using DECIPHER v2.0 to analyze big biological sequence data in R. R J. 2016;8(1):352-9

67. Silver LM. Mouse genetics : concepts and applications. New York: Oxford University Press; 1995. xiii, 362 p. p.

68. Schindelin J, Arganda-Carreras I, Frise E, Kaynig V, Longair M, Pietzsch T, et al. Fiji: an open-source platform for biological-image analysis. Nat Methods. 2012;9(7):676-82.

\section{Publisher's Note}

Springer Nature remains neutral with regard to jurisdictional claims in published maps and institutional affiliations.

Ready to submit your research? Choose BMC and benefit from:

- fast, convenient online submission

- thorough peer review by experienced researchers in your field

- rapid publication on acceptance

- support for research data, including large and complex data types

- gold Open Access which fosters wider collaboration and increased citations

- maximum visibility for your research: over $100 \mathrm{M}$ website views per year

At BMC, research is always in progress.

Learn more biomedcentral.com/submissions 